\title{
TOPOGRAPHIC POSITION INDEX BASED LANDFORM ANALYSIS OF MESSARIA (IKARIA ISLAND, GREECE)
}

DOI: https://doi.org/10.18509/AGB.2018.01

UDK: 550.81:528.42

\author{
Athanasios Skentos ${ }^{1,2}$ \\ ${ }^{1}$ National and Kapodistrian University of Athens, Greece, ${ }^{2}$ Mott Macdonald Ltd, United Kingdom \\ Corresponding author: athanasios.skentos@mottmac.com
}

Submitted: January 2017, Accepted: May 2017, Published: October 2017

\begin{abstract}
This paper aims to classify and analyze landforms in the broader area of Messaria region of Ikaria Island, Greece using GIS techniques. Landform categories were determined by implementing Topographic Position Index (TPI). The classes obtained from the TPI were related with the geological pattern of the study area for further interpretation of the landform evolution. The analysis of the data indicates the presence of three landform units in the study area, affected mainly by geology.
\end{abstract}

Key words: Geology, Geomorphometry, TPI, DEM, Ikaria Island

\section{Introduction}

Over the last decade, Digital Elevation Models have been widely used to automatically classify landforms [3], [4], [5], [9], [11], [13]. Either by computing differential geometry algorithms or by defining spatial patterns, both approaches focus on the following: to reduce time consumption and generalize local findings. As a result, a large number of studies have been introduced for the interpretation of complex data regarding morphometry, morphostructure and morphogenesis. From a geomorphological point of view, landforms are of particular interest as they contribute significantly to the geomorphological interpretation.

The strong relationship between rock type, structure and the ensuing topography determines both landforms and landscape alternations [5]. Therefore, relating landform classes with the geological pattern is of great significance [11]. The broader area of Messaria region, occupying the central part of Ikaria Island (Greece), was selected for landform analysis due to its complex geology and the diverse morphology of the relief. The main goal of this paper is the interpretation of the landform classes of the study area, automatically derived by processing Topographic Position Indices, with the local geology.

\section{Study area}

Ikaria is a Greek island located at the eastern part of the Aegean Sea (Fig. 1A). Occupying an area of approx. $250 \mathrm{~km}$, the island has an elongated shape directed from SW to NE and can be described as mountainous where plateaus, ranges of hills and low mountains are the dominant landforms (Fig 1B). The gradient of the relief is much lower close to the south coast and the hydrographic network much more developed along the north flank of the island [12]. The targeted research area, featuring Messaria and its vicinity region at the south, occupies the central part of the island where several distinctive environments occur. In particular, the square study area is bounded by Mount Atheras to the south whilst at the north, the Aegean Sea (Fig. 1C). Voutsides is the main river of the study area that drains Atheras Mountain to the northern shore (Fig. 1C). 


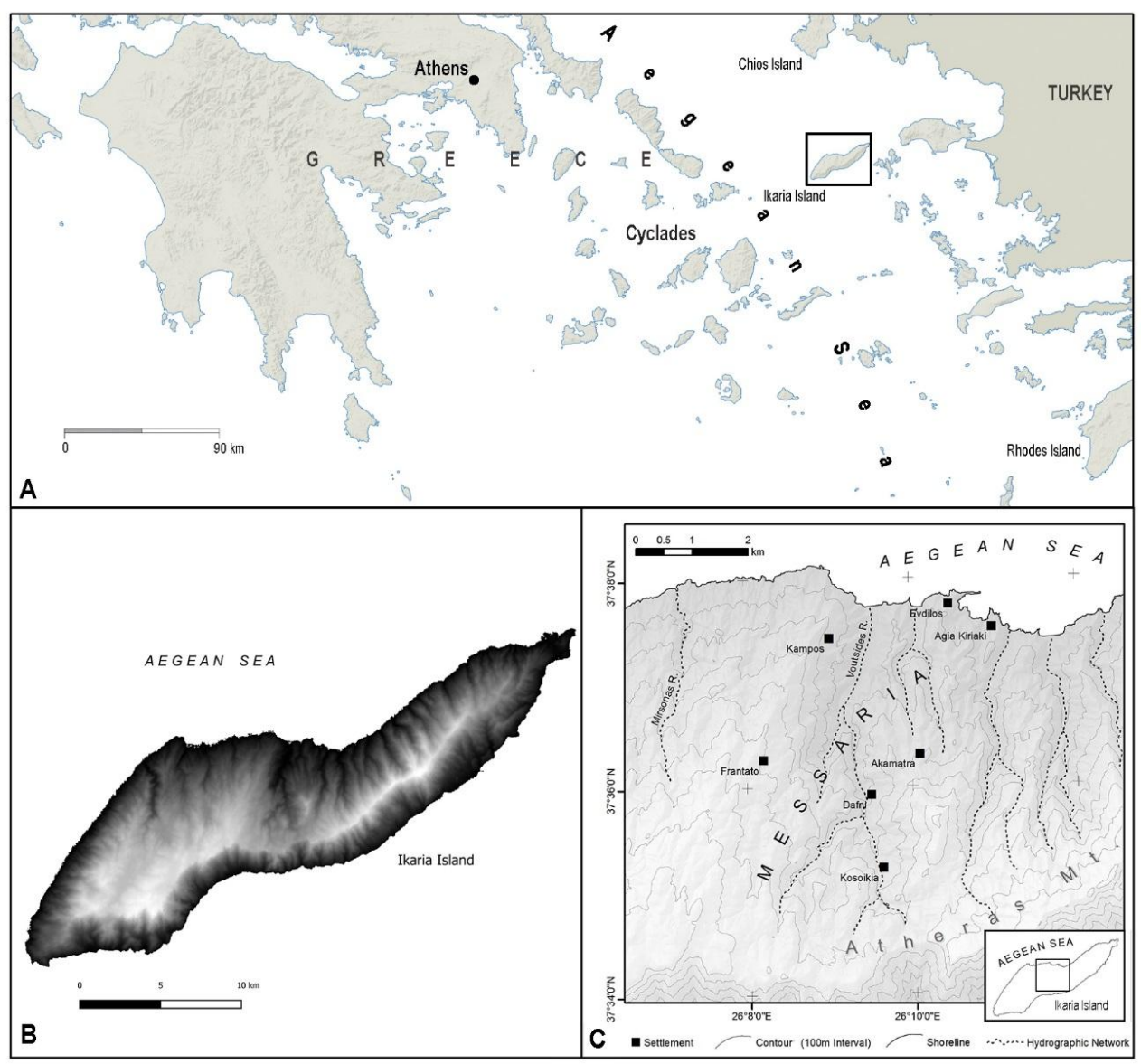

Figure 1: A) Location map, B) Terrain of Ikaria Island, C) Study area.

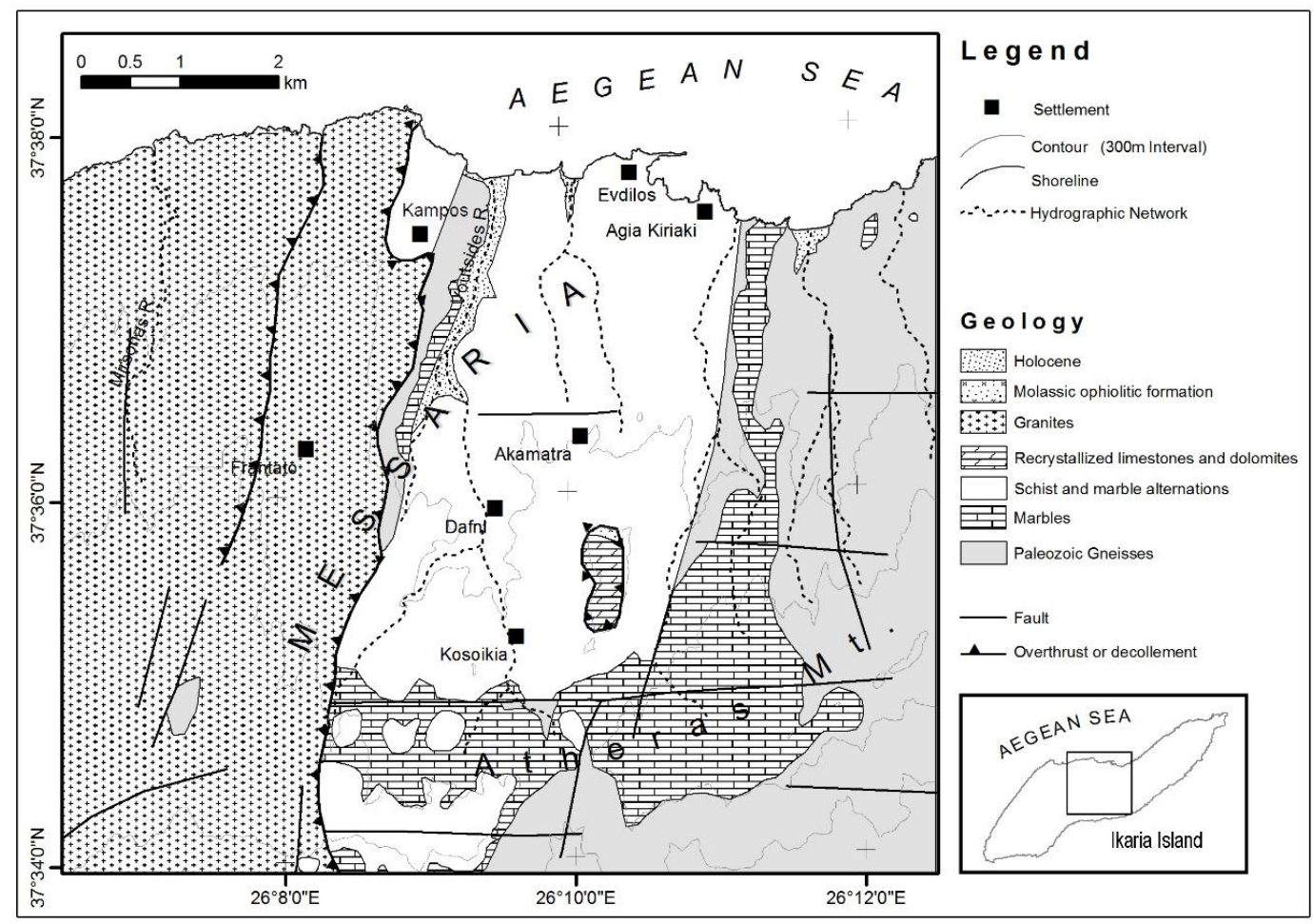

Figure 2: Simplified geological map of the study area. 
The complex geology of Ikaria Island is due to its transitional geotectonic position between the Attic-Cycladic Crystalline Complex and the Pelagonian Zone to the west, and the Menderes Massif to the east [1], [6]. Geologically speaking, the island consists of a gneissic basement, overlain by a sequence of schist and marble alternations, characterized by granite intrusion [6]. Regarding the study area, the western part is dominated by granites, bounded by an overthrust fault directed from south to north (Fig. 2). In contrast, the eastern part of the study area, presents a complex geology of metamorphic rocks. Holocene deposits can be observed at the end of the valleys, just before the beach front (Fig. 2). Of utmost significance is the elongated Holocene coastal plain, formed at Voutsides River downstream (Fig. 2).

\section{Data \& Methodology}

\section{Data Used}

For the purpose of this study, a high resolution Digital Elevation Model (DEM) was used, obtained by Ktimatologio SA. Additionally, a medium scale (1:50.000) topographic map of Ikaria Island produced by the Hellenic Military Geographical Service was used for the allocation of the settlements and the mapping of the river network. Lastly, the geological data were digitized by the analogue geological map of Ikaria Island produced by the Institute of Geological and Mineral Exploration of Greece in scale 1:50.000. All data were processed by applying geospatial tools through open source software GIS (QGIS, SAGA).

\section{Calculating topographic attributes}

A GIS was implemented for the calculation of the appropriate attributes in order to conduct landform analysis. In general, the implementation process is described in figure 3. In particular, a high resolution DEM $\left(25 \mathrm{~m}^{2}\right.$ pixel size) was used in order to compute the following topographic attributes: slope, valley depth and Topographic Position Indices (TPI) (Fig. 3). Before calculating these attributes, the Planchon/Darboux algorithm was used in SAGA GIS toolbox to fill DEM's depressions in order to eliminate DEM mistakes [7]. In addition, the pre-processing techniques include the application of a 25-meter radius Gaussian filter to smoothen the DEM before computing valley depth and TPI (Fig. 3). As a result, the outputs are spatially more coherent and interpretable.

Slope expresses the inclination of the surface of the terrain from the horizontal plane [10]. The slope map presented in this study is calculated in degrees (Fig. 4A).Valley depth was calculated by using the homonym algorithm on SAGA GIS [2]. In particular, the specified algorithm measures the vertical distance (calculated in meters) from ridges (channel network derived by inverted DEM) to a river network base level (Fig. 4B).

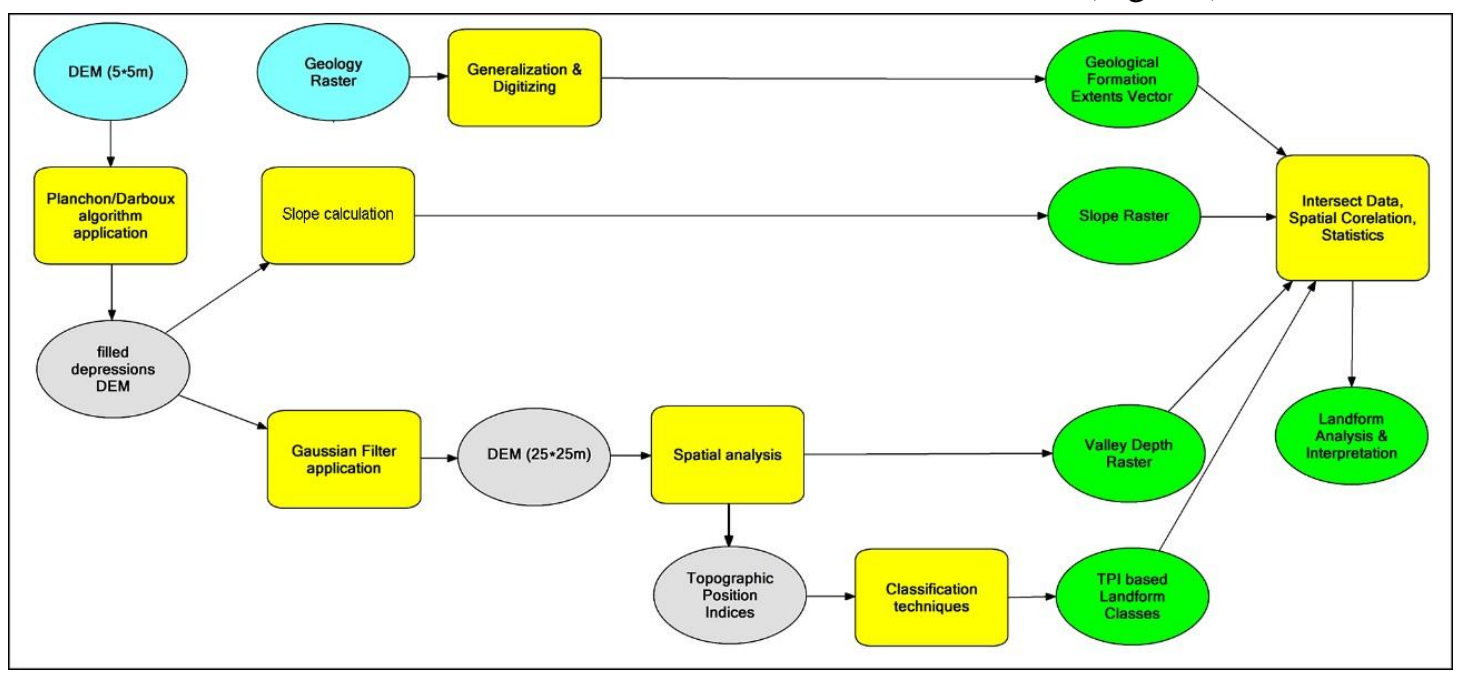

Figure 3: Generalized flow diagram describing the methodology of the research; cyan: input data, yellow: data processing, grey: intermediate data, green: output data (results). 
Topographic Position Index (TPI) is defined as the difference between the elevation at a cell and the average elevation of cells that surround it within a predetermined radius [14].

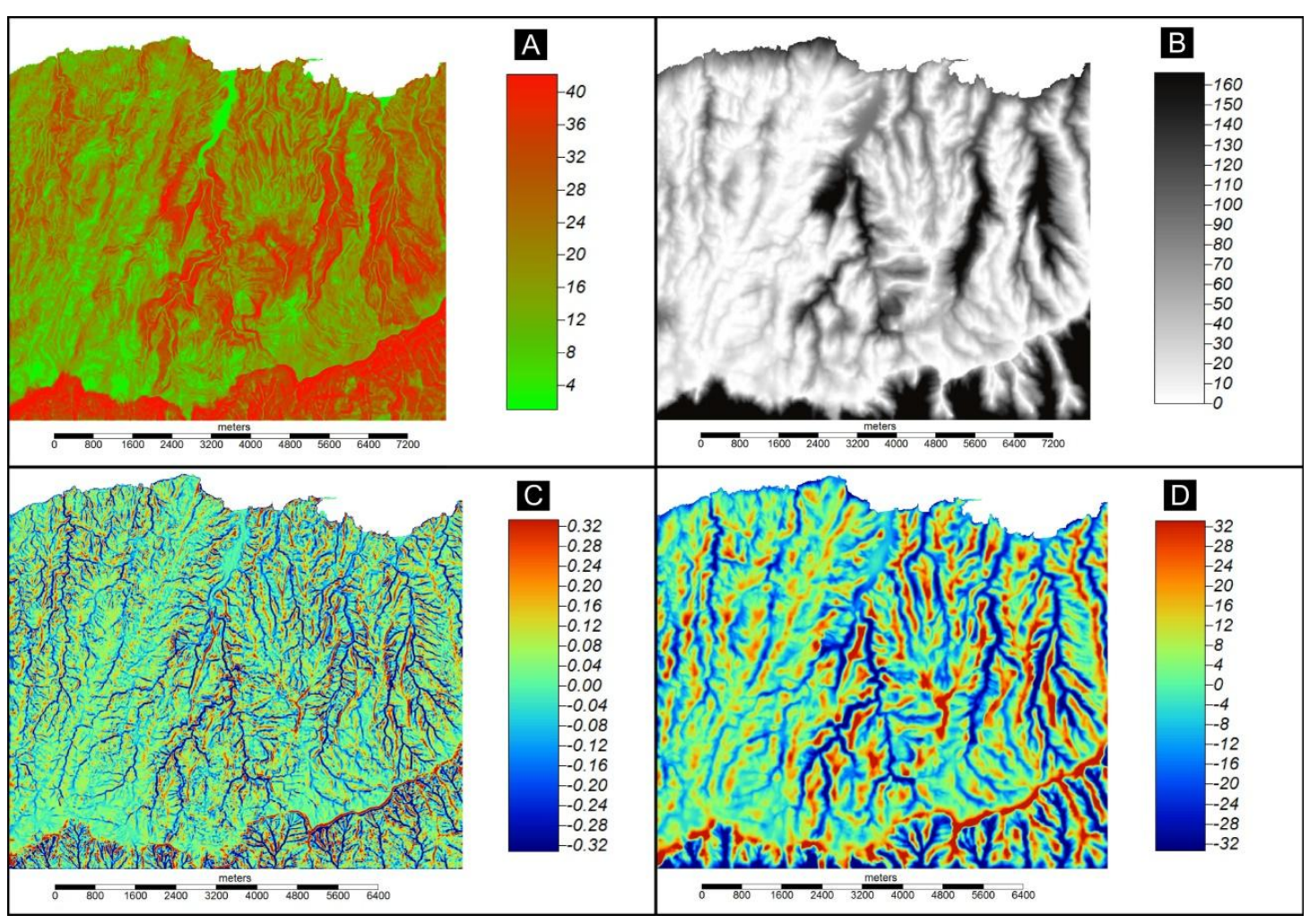

Figure 4: A) Slope map (degrees), B) Valley depth (meters),

C) TPI (Radius=10m.), D) TPI (Radius=200m.).

TPI values above zero show locations that are higher than the average of the local window e.g. ridges. In contrast, negative TPI values represent locations that are lower e.g. valleys. Lastly, TPI values near zero represent areas of constant slope. The range of TPI depends on the neighborhood size [4]. Therefore, large radius values reveal major landscape units, while smaller values highlight relatively small landforms (Fig. 4C, Fig. 4D).

\section{Landform classification \& interpretation}

TPI values calculated from two different radius $(\mathrm{R})$ values $(10 \mathrm{~m}$. and $200 \mathrm{~m}$. ones) provide more detailed information about the general shape of the landscape rather than the TPI values from just a single neighborhood. Therefore, the combination of TPI grids generated at different scales results in the identification of complex landforms [13]. Since elevation tends to be spatially auto correlated, the range of TPI values increases with scale. This issue can be tackled by standardizing the TPI grids to mean $=0$ and standard deviation $=1$ [14]. The two TPI rasters $(10 \mathrm{~m}$. and $200 \mathrm{~m}$. neighborhood respectively) selected as input data to the TPI based landform classification module on SAGA GIS, resulted to the ten landform classes of the study area, as shown on figure 5. The derived landform classes were intersected with the geology, slope, and valley depth on QGIS for the landscape interpretation. Prior the intersection, slope and valley depth were both categorized in five distinctive classes. 


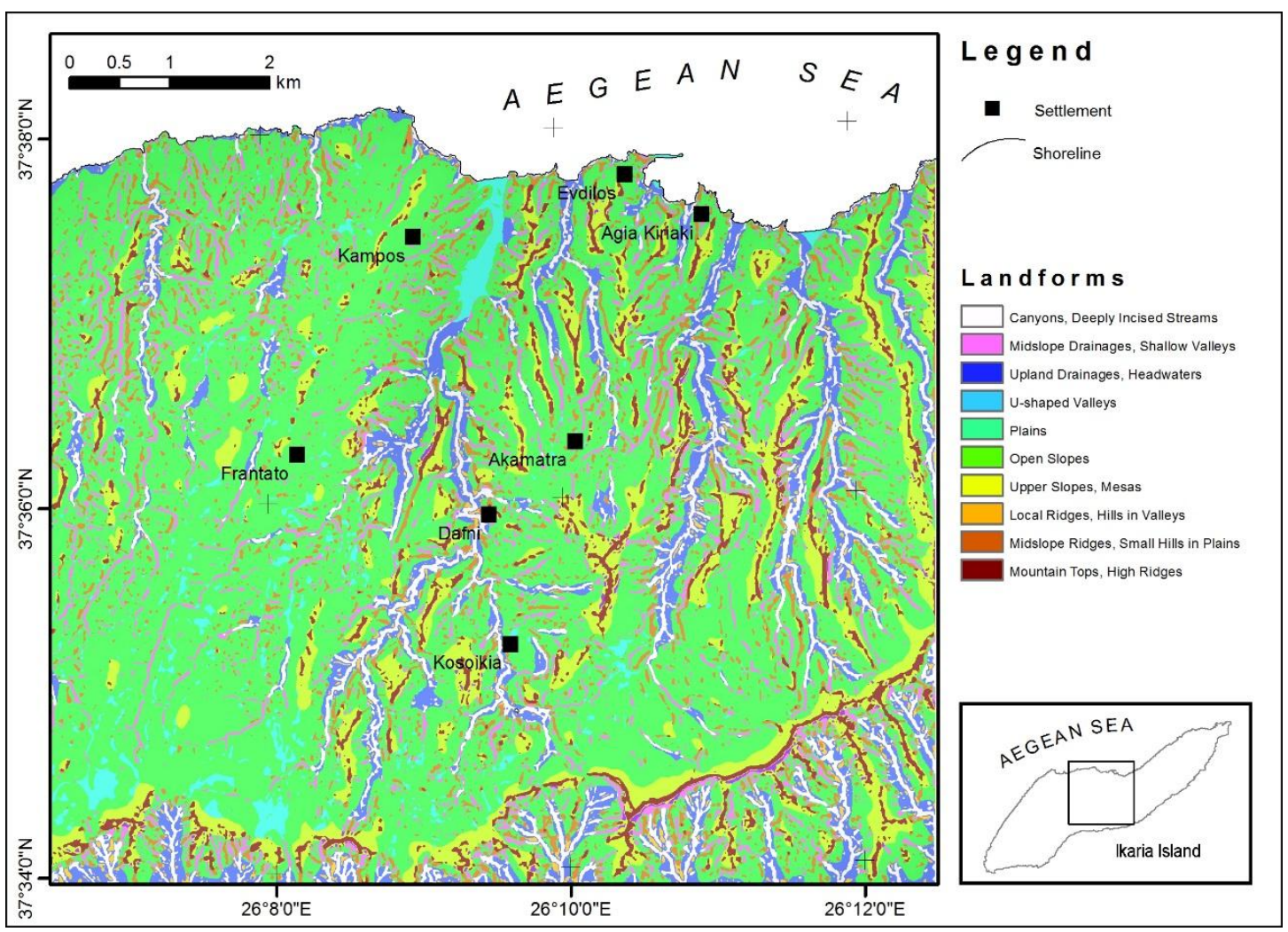

Figure 5: Landform Classification based on combined TPI $\left(R_{1}=10 m \& R_{2}=200 m\right)$.

\section{Results and discussion}

Further statistical analysis of the TPI based landform classification, led to the percentage calculation of each landform class (Fig. 6). According to figure 6, open slopes is the dominant class of the study area $(57.25 \%)$ whilst local ridges, hills in valleys and upland drainages, headwaters appear to be of low significance, since they both cover $1 \%$ of the study area.

\begin{tabular}{|c|c|}
\hline 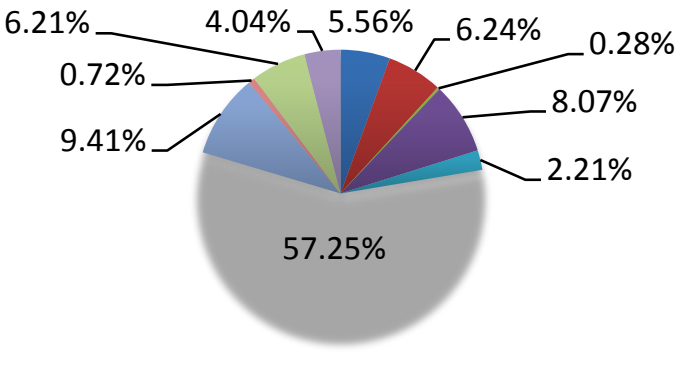 & $\begin{array}{l}\text { Canyos, Deeply Incised Streams } \\
\text { Midslope Drainages, Shallow Valleys } \\
\text { Upland Drainages, Headwaters } \\
\text { - U-shaped Valleys } \\
\text { - Plains } \\
\text { Open Slopes } \\
\text { - Upper Slopes, Mesas } \\
\text { - Local Ridges, Hills in Valleys } \\
\text { Midslope Ridges, Small Hills in Plains } \\
\text { - Mountain Tops, High Ridges }\end{array}$ \\
\hline
\end{tabular}

Figure 6: Percentage of Landform Classes.

Table 1 shows the percentage distribution of the landform classes on each and every geological formation. Granites that cover the western part of the study area are strongly related to open slopes (over 69\%). In contrast, the eastern part of the study area, dominated by metamorphic rocks, presents a greater diversity of landforms (Table 1). Lastly, the area lying south of Atheras Mount ridge presents an intense relief regardless the bedrock geology. 
Table 1: Landform Classes related to geology.

\begin{tabular}{|c|c|c|c|c|c|c|c|}
\hline & Granites & Holocene & Marbles & $\begin{array}{l}\text { Molassic } \\
\text { ophiolitic } \\
\text { formation }\end{array}$ & $\begin{array}{l}\text { Paleozoic } \\
\text { Gneisses }\end{array}$ & $\begin{array}{c}\text { Recrystalliz } \\
\text { ed } \\
\text { limestones } \\
\text { and } \\
\text { dolomites }\end{array}$ & $\begin{array}{l}\text { Schist and } \\
\text { marble } \\
\text { alternations }\end{array}$ \\
\hline $\begin{array}{l}\text { Canyons, Deeply } \\
\text { Incised Streams }\end{array}$ & $2.80 \%$ & $8.90 \%$ & $4.10 \%$ & $0.00 \%$ & $9.92 \%$ & $0.60 \%$ & $6.28 \%$ \\
\hline $\begin{array}{l}\text { Midslope Drainages, } \\
\text { Shallow Valleys }\end{array}$ & $6.51 \%$ & $2.38 \%$ & $6.31 \%$ & $0.21 \%$ & $6.19 \%$ & $3.27 \%$ & $6.07 \%$ \\
\hline $\begin{array}{l}\text { Upland Drainages, } \\
\text { Headwaters }\end{array}$ & $0.08 \%$ & $0.00 \%$ & $0.76 \%$ & $3.43 \%$ & $0.28 \%$ & $2.91 \%$ & $0.26 \%$ \\
\hline U-shaped Valleys & $4.23 \%$ & $22.40 \%$ & $4.99 \%$ & $0.00 \%$ & $14.14 \%$ & $0.46 \%$ & $9.29 \%$ \\
\hline Plains & $3.58 \%$ & $32.46 \%$ & $1.41 \%$ & $0.00 \%$ & $0.16 \%$ & $0.00 \%$ & $1.29 \%$ \\
\hline Open Slopes & $69.29 \%$ & $28.08 \%$ & $59.12 \%$ & $13.07 \%$ & $43.52 \%$ & $30.64 \%$ & $52.95 \%$ \\
\hline $\begin{array}{l}\text { Upper Slopes, } \\
\text { Mesas }\end{array}$ & $5.58 \%$ & $0.04 \%$ & $12.59 \%$ & $59.46 \%$ & $11.52 \%$ & $41.98 \%$ & $11.26 \%$ \\
\hline $\begin{array}{l}\text { Local Ridges, Hills } \\
\text { in Valleys }\end{array}$ & $0.33 \%$ & $0.28 \%$ & $0.48 \%$ & $0.00 \%$ & $1.58 \%$ & $0.09 \%$ & $0.70 \%$ \\
\hline $\begin{array}{l}\text { Midslope Ridges, } \\
\text { Small Hills in Plains }\end{array}$ & $5.63 \%$ & $5.09 \%$ & $4.87 \%$ & $2.39 \%$ & $7.43 \%$ & $1.17 \%$ & $6.73 \%$ \\
\hline $\begin{array}{l}\text { Mountain Tops, } \\
\text { High Ridges }\end{array}$ & $1.95 \%$ & $0.37 \%$ & $5.37 \%$ & $21.44 \%$ & $5.25 \%$ & $18.87 \%$ & $5.18 \%$ \\
\hline
\end{tabular}

Taking local geology, the ensuing topography and the landform allocation into consideration, it appears to be that the study area could be further subdivided into three landform units; S1, NW1, NE1 (Fig. 7). These units were manually determined using as bounding lines the ridge of Atheras Mount and the overthrust fault. In particular, the S1 unit covers the southern part of the study area, bounded by the centerline of the Atheras Mount ridge. The area is characterized by steep slopes forming alternations of ridges and valleys. The highest slope appeared in $\mathrm{S} 1$ is over $70^{\circ}$. Approximately $30 \%$ of the slopes are categorized as steep $\left(>35^{\circ}\right)$ (Fig. 8). Additionally, almost $40 \%$ of the valleys are over 150 meters deep (Fig 9).

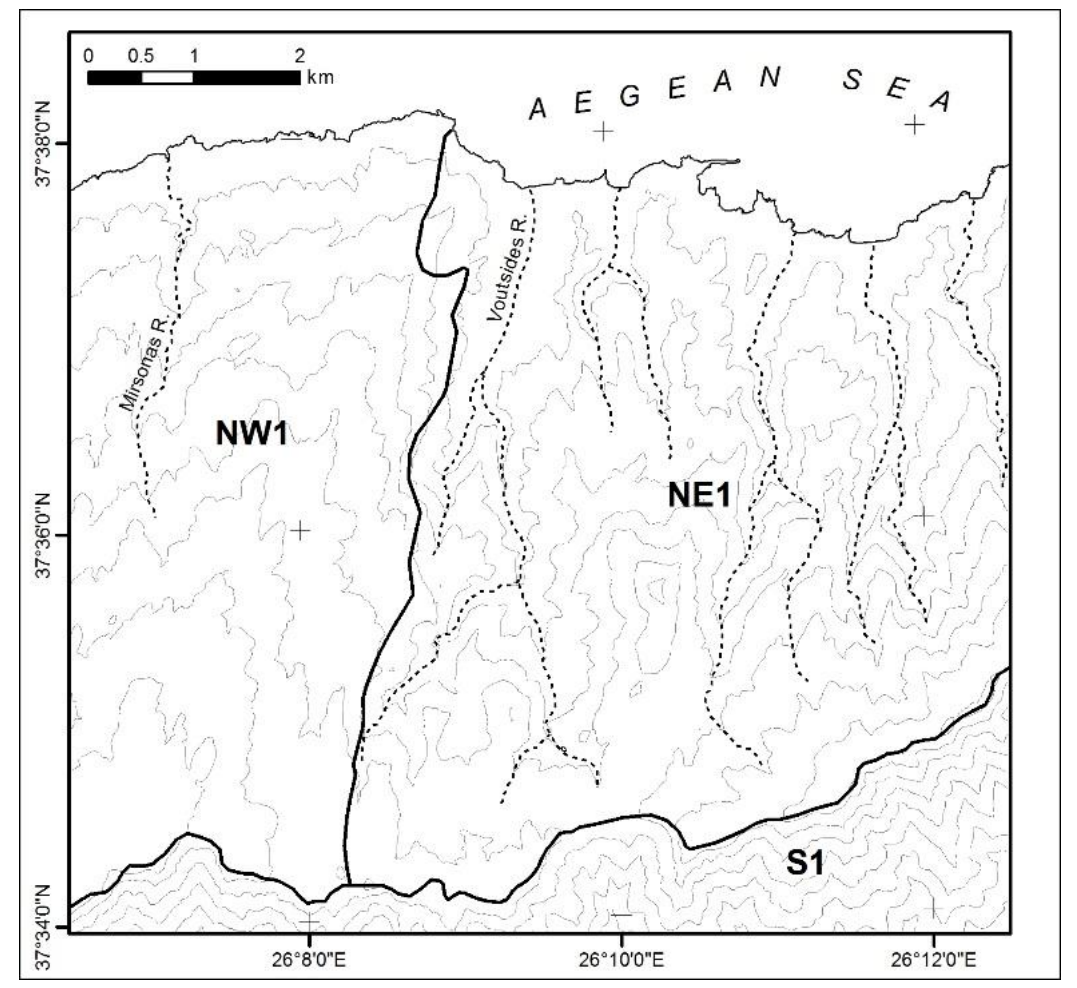

Figure 7: Landform Units 
The land lying to the north of Atheras Mount ridge (the main part of Messaria region) could be further subdivided into 2 units. The overthrust fault directed from south to north seems to be the boundary line that separates NW1 from NE1 unit (Fig. 7). On the west side, the terrain seems to be smoother presenting a mean slope of $16^{\circ}$ and a standard deviation of

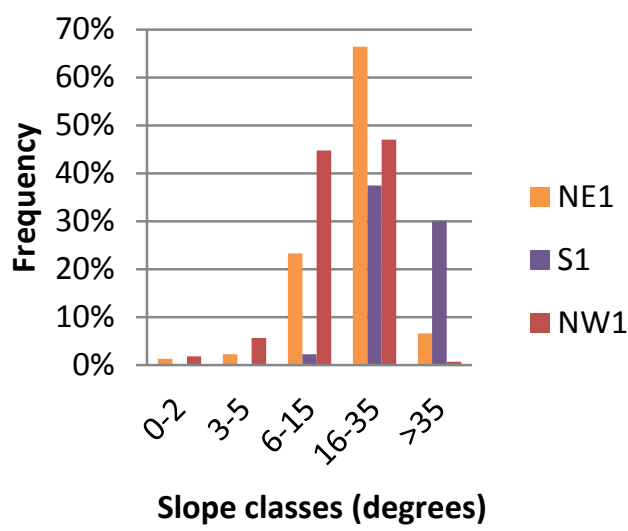

Figure 8: Slope classes for each unit.

The slopes between $16-35^{\circ}$ cover $65 \%$ of the NE1 unit (Fig. 8). Another index that shows the difference between NW1 and NE1 is the valley depth. Specifically, over $65 \%$ of NW1 unit presents valleys that are no more than 20 meters deep (Fig. 9). In contrast, almost $75 \%$ of NE1's valleys are deeper than 20 meters (Fig. 9).

All in all, it seems that both geology and topography are contributory factors to the landform evolution of the study area. The landscape of NW1 unit is mainly affected by the Granites that cover almost the whole area. Thus, there is no developed hydrographic network to boost the geomorphological processes of erosion and deposition. Therefore, no Holocene deposits appear, not even at the beachfront. However, in situ recent deposits created by the weathering of Granites can be found at shallow valleys. As a result, NW1 is dominated by open slopes, occasionally interrupted by shallow valleys. Contrary, the carbonate formations that cover the NE1 unit were easily eroded forming a total different landform evolution. As a result, the area presents a developed hydrographic network, alternation of ridges and valleys
7.32. Over $90 \%$ of the slopes are classified between $6-35^{\circ}$ (Fig. 8). On the other side, the NE1 unit, presents a more complex landscape associated mainly with the hydrographic network. Therefore, valleys and local ridges directed from south to north are the dominant landforms. The mean slope is $22^{\circ}$ and the standard deviation is 9.25 .

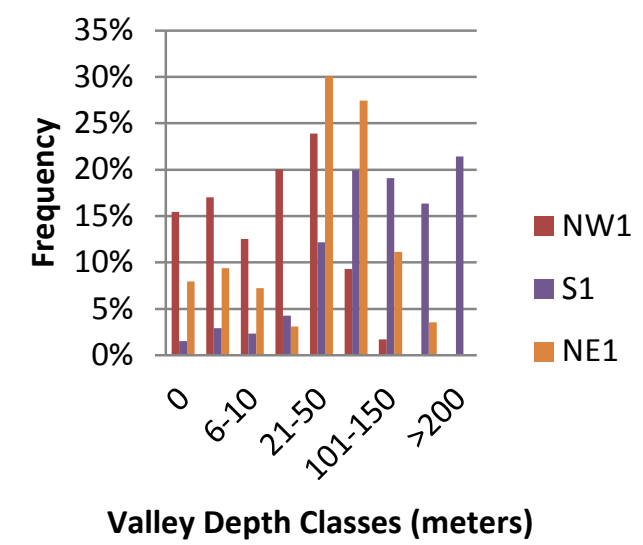

Figure 9: Valley Depth classes for each unit and recent deposits at the beach front. Lastly, the S1 landform unit presents a complex and diverse morphostructure that appears to have no connection with the local geological setting.

\section{Conclusions}

Topographic Position Index (TPI) has proven to be a useful geoprocessing tool concerning landform classification and interpretation. However, this study indicates that landform analysis is more coherent and interpretable by relating the output landform classes to the local geological setting. In particular, the intersection of the TPI derived landforms with the local geology of Messaria region led to the identification of three landform units. The S1 unit (lying to the south of Atheras Mount ridge) is characterized by complex geology, steep slopes, valleys and ridges alternations, and highly developed hydrographic network. The NW1 unit (covering the northwestern part of the study area) is characterized by the dominance of open slopes (over $70 \%$ of study area), in situ deposition (caused by Granites weathering), and poor development of hydrographic network. 
Lastly, the NE1 unit (lying to the northeast), covered by the easily eroded carbonate formations, is characterized by a developed hydrographic network, alternation of ridges and valleys and recent deposits at the beach front.

At this point it should be mentioned that the greatest advantage of the TPI (like all automated algorithms) is the reduction of time needed for the outputs. However, by inserting qualitative data like geology into the data processing, the time required for the research increases significantly. Moreover, different approaches on the quantification of such data (e.g. grouping of geological formations and/or age) might lead to confusing results. Nevertheless, the implementation of a widely accepted quantification process of the geological information could eliminate the above weaknesses and turn geology into a contributory factor for accurate automated landform analysis.

Acknowledgements: This paper is part of the $\mathrm{PhD}$ in progress entitled "Spatial model implementation for the analysis of the geographical and geomorphological data of Ikaria Island using automated GIS techniques"

\section{References}

[1] Bozkurt E. \& Oberhansli R. Menderes Massif (Western Turkey): structural, metamorphic and magmatic evolution - a synthesis. International Journal of Earth Sciences 89, 679-708, 2001.

[2] Conrad, O., Bechtel, B., Bock, M., Dietrich, H., Fischer, E., Gerlitz, L., Wehberg, J., Wichmann, V., and Böhner, J.: System for Automated Geoscientific Analyses (SAGA) v. 2.1.4, Geosci. Model Dev., 8, 1991-2007, 2015.

[3] De Reu J., Bourgeois J., Bats M., Zwervaegher A., Gelorini V., De Smedt P., Chu W., Antrop M., De Maeer P., Finke P., Van Meirvenne M., Verniers J., Crombe P. Application of the topographic position index to heterogeneous landscapes. Geomorphology, 186, 39-49, 2013.

[4] Grohmann C.H., Riccomini C. Comparison of roving-window and search-window techniques for characterizing landscape morphometry. Computers and Geosciences 35, 2164-2169, 2009.

[5] Ilia I., Rozos D., Koumantakis I. Landform classification using GIS techniques. The case of Kimi municipality area, Euboea Island, Greece. Bulletin of the Geological Society of Greece, Vol XLVII 2013, Proceedings of the 13th International Congress, Chania, 2013.

[6] Ktenas K. \& Marinos P. G. Ikaria island geology. IGME, vol. XIII, VOL Geological and Geophysical research, No 2, Athens, 1969.

[7] Planchon O., \& Darboux F. A fast, simple and versatile algorithm to fill the depressions of digital elevation models. Catena 46: 159-176, 2001.

[8] Riley, S.J., De Gloria, S.D., Elliot, R. A Terrain Ruggedness that Quantifies Topographic Heterogeneity. Intermountain Journal of Science, Vol.5, No.1-4, pp.2327, 1999.

[9] Rigol-Sanchez J.P., Stuart N., Pulido-Bosch A. ArcGeomorphometry: A toolbox for geomorphometric characterization of DEMs in the ArcGIS environment. Computers \& Geosciences 85, 155-163, 2015.

[10] Senthilvelan, A. A Gis Based Study on Slope Characteristics of Porandalar Watershed, Amaravathi Sub-Basin, Tamil Nadu. In: Indian Journal of Applied Research, 5 (12), 1-3, 2015. 
[11] Skentos A., Ourania O. Landform analysis using terrain attributes. A Gis application on the island of Ikaria (Aegean Sea, Greece). Annals of Valahia University of Targoviste, Geographical Series, Vol 17 (1), 90-97, 2017

[12] Stiros S. C., Laborel J., Laborel-Deguen F., Morhange C. Quaternary and Holocene coastal uplift in Ikaria Island, Aegean Sea. Geodinamica Acta, 24:3-4, 123-131, 2011.

[13] Tagil S. \& Jenness J. GIS-based automated landform classification and topographic, landcover and geologic attributes of landforms around the Yazoren Polje, Turkey. Journal of Applied Sciences 8, 910-921, 2008.

[14] Weiss A.D. Topographic position and landforms analysis. ESRI Users Conference, San Diego, CA, USA, 2001. 